\title{
Primary Analysis of Co-Creation Method: A Conceptual Framework for Malaysian Interactive Product Development
}

\author{
Ramlan Jantan ${ }^{1}$, Norfadilah Kamaruddin², Shahriman Zainal Abidin² \\ ${ }^{1}$ Faculty of Art, Computer \& Industry Creative, Sultan Idris Education University Tanjung Malim Perak Malaysia \\ 2Faculty of Art \& Design, Universiti Teknologi MARA 40450 Shah Alam Selangor Malaysia \\ sussaint@gmail.com, norfadilah@uitm.edu.my, shahriman.z.a@uitm.edu.my \\ Tel: +60192049729
}

\begin{abstract}
Nowadays, the co-creation method has become a new development trend in the era of technology. Towards this scenario, design industry firms currently have transformed their development strategy from a good-dominant into service-dominant and more attention given to end-users in the development process. As a result, the conventional development process has been replaced with more cooperative development which is customer focus. Most of the Results from established sources such as journals and books have concluded. The framework is accumulated from both parties involved: the users and designers. This paper further contributes to the literature on the co-creation of value and digital ecosystems.
\end{abstract}

Keywords: co-creation method; co-creation framework; co-creation

eISSN: 2398-4287 @ 2019. The Authors. Published for AMER ABRA cE-Bs by e-International Publishing House, Ltd., UK. This is an open access article under the CC BYNC-ND license (http://creativecommons.org/licenses/by-nc-nd/4.0/). Peer-review under responsibility of AMER (Association of Malaysian Environment-Behaviour Researchers), ABRA (Association of Behavioural Researchers on Asians), and CE-Bs (Centre for Environment-Behaviour Studies), Faculty of Architecture, Planning \& Surveying, Universiti Teknologi MARA, Malaysia.

DOI: https://doi.org/10.21834/ebpj.v5iSI1.2309

\subsection{Introduction}

A co-creation method is a new form of open innovation where people share, rather than keep their ideas and experiences together. Besides, co-creation methods are being used internally to build relationships within the organization. During the last decade, co-creation value research has evolved rapidly. It has been receiving considerable attention from researchers and practitioners (Roser et al., 2009). Although its uniqueness on building inter-relationships between customers and designers, the value of the co-creation method still being argued and still un-clear by some scholars. Issues have risen including whether value-in-use or nature of the co-creation method.

In the state-of-art, many researchers expanded on researching the components of co-creation value in the development process. While in the state-of-practice, based on designers' perspectives, they tried to focus on the needs of end-user to create value regardless of how. As a result, new models of co-creation value and techniques have been developed and presented. Nevertheless, even though such efforts were significant, it failed to explicate how real value can be created (Grönroos and Voima 2012). There is a need to explore the process of co-creation value to enrich and facilitate the development and usage of new products and services. Hence, by taking a few existing co-creation models, this research explored and explicated more on the co-creation for Malaysian interactive product development.

So far, a lot of explorations were conducted by numerous researchers tremendously to find whether the co-creation method can be realized in the practice of design services (Galvagno, Gummesson, et al. 2014). In addition to all that, the designers also tried to reach a new meaning on how the co-creation has been integrated by users during the design process. Although, many of the new models were developed to make the design process easier, however, the arguments that have been raised by academia is whether the concept of co-creation is highly prepared a holistic framework that shared values of both participants. Nevertheless, a concept of multi-faceted framework thus will answer a new exploration to find what and how co-creation value applicable in Malaysian design industries.

eISSN: 2398-4287 ( 2019. The Authors. Published for AMER ABRA cE-Bs by e-International Publishing House, Ltd., UK. This is an open access article under the CC BYNC-ND license (http://creativecommons.org/licenses/by-nc-nd/4.0/). Peer-review under responsibility of AMER (Association of Malaysian Environment-Behaviour Researchers), ABRA (Association of Behavioural Researchers on Asians), and cE-Bs (Centre for Environment-Behaviour Studies), Faculty of Architecture, Planning \& Surveying, Universiti Teknologi MARA, Malaysia.

DOI: https://doi.org/10.21834/ebpj.v5iSI1.2309 


\subsection{The Nature of Co-Creation Concept}

Co-creation consists of individuals, or other organizations, interacting with organizations to develop value. This concept is, generally, beneficial for both: developer companies and their collaborators. According to the various literature, 'Co-Creation' established the theoretical roots of the concept coming from several fields such as:

1. Co-creation of value - from a Marketing and R\&D perspective

2. Co-creation of meaning -from a Psychological and Sociological perspective

3. Co-creation processes -from the viewpoints such as decision making, innovation and change management

4.Co-creation -as in innovation practice

By understanding how co-creation works, it will be possible to understand the relations of how it works, strategies, and their effects on different stakeholders, in particular the customer. Firstly, a clarification of the co-creation concept is presented in Table 1 below, in which a few ideas are related and similar to the co-creation concept.

Table 1: Co-creation concept

\begin{tabular}{lll}
\hline Concepts & Terminology of Co-Creation & Scholars \\
\hline Co-production & $\begin{array}{l}\text { It refers to co-creation cases where the collaboration is } \\
\text { closer to the core production of the concept. }\end{array}$ & $\begin{array}{l}\text { Lush \& Vargo } \\
\text { (2006) }\end{array}$ \\
\hline User-driven & $\begin{array}{l}\text { consists in lead uscrs and individuals or organizations in } \\
\text { need of certain solutions being the ones to develop } \\
\text { such new technologies and innovation. }\end{array}$ & Von Hippel (2005) \\
\hline Collaborative & $\begin{array}{l}\text { As communities and end users that collaborate with } \\
\text { companies to develop new products. }\end{array}$ & Cova \& Dali (2009) \\
\hline Open Innovation & $\begin{array}{l}\text { Consists on finding talents outside an organization to } \\
\text { solve a specific solution to a highly technical problem. } \\
\text { May differ from co-creation as it requires a specific } \\
\text { solution to a specific need, it becomes more of an } \\
\text { outsourcing concept than an interaction }\end{array}$ & Badani (2011) \\
\hline & $\begin{array}{l}\text { It consists of the outsourcing of company processes to } \\
\text { cxternal collaborators or crowds. It is considered co- } \\
\text { creation when interaction and relations with the } \\
\text { organization occur following the initial interaction. }\end{array}$ & $\begin{array}{l}\text { Youseph (2011) } \\
\text { Crowdsourcing (2006) }\end{array}$ \\
\hline
\end{tabular}

In promoting this popular concept, Ramaswamy and Gouillart (2010) explained how corporations are the best practice of the cocreation concept. They moreover stated that the "future belongs to co-creative enterprises" and it requires democratization and decentralization of value creation, meaning the necessity of creating constant interaction with customers, partners, and employees. Further, they also stated that the principle of co-creation has four components, including i) mindset experience; (ii) context of interpretations; (iii) engagement platforms; and (iv) network relationships. By combining these components correctly, organizations will be able to unleash the four powers of co-creation namely: increased strategic capital and returns to enterprises; lower risks and costs for enterprises; new experiences of value to individuals; and lower risks and costs for individuals.

Similarly, Porter (2012) suggested that co-creation value involves not only supplies' and customers' respective value-creation processes, but also the encounter process, which refers to the procedures and practices of interaction and exchange between the parties. Such encounter processes are exchange practices in which the parties exchange resources, as well as collaborative ways in which the parties jointly perform activities (Webber, M. and Robinson, K, 2011). In the service context, this encounter process allows person-to-person interaction, mutual learning, and customization of the offering. Moreover, through the encounter process, the supplier can get involved in aiding the customer to make use of the resource provided. The encounter process is, therefore, an essential part of the value-creation processes of the actors involved, and it influences the role that the supplier can assume in the customer's value creation process (Porter, 2012).

Strokosch (2013) notes that the supplier and the customer are not the only actors involved in service creation, but a host of other stakeholders influence value creation. As organizations become more and more specialized, they may exchange with other organizations to form networks that can provide a broader set of services or solutions. As Cornwell and Campbell (2012) note, service innovations are dependent on the collection of competencies, which the firm can continually renew, create, integrate, and transform. Given the immense pressure on firms to continuously find ways to develop new services at a fast speed (Lusch \& Nambisan, 2015), new service concepts offered to the customer are increasingly the result of co-operation or co-creation of a network of companies.

Vargo \& Lusch, 2004 continue with a statement describing the system function "Hence, value creation occurs in networks in which resources are exchanged among multiple actors and is, therefore, more accurately conceptualized as value co-creation (Vargo and Lusch, 2008, Vargo, Maglio and Akaka, 2009)". To illustrate, input provided by the user as an actor is necessary to create new values in the early pre-production process. Information provided could be such as concept and visualization and can determine the initial creation of products and the outcome as well. 
Companies offering a joint service concept with network partners are then involved in value creation not only for themselves, and with their customer, but also for and with their co-suppliers.

Taking in consideration this empowerment of the internet towards its users, as in access to information and speed of communication platforms, it becomes evident that this new customer is starting to become involved in innovation processes becoming a promising area of marketing and strategy (Prandelli, Verona, \& Raccagni, 2006)

\subsection{Methodology}

Today, firm roles have changed after the advancement of technology, shift from operant resources to providers of resources. Hence, the firm no longer involves operate as an operant resource, but almost every decision today is provided by the user or customer. Moreover, the firm the only provider of resources and allowed every decision makes by customers or users. As an advancement of technology that's shifted the future of co-creation, roles of firm and user are not clearly defined by the latest research today. Hence, most research still argued on a characteristic of value creation and less on influences of technology that shifted firm roles. Suggested by Prahalad, 2004, the part of customer evolved, and the customer is a creator of firm scripted strategy. (Prahalad, C. K. Ramaswamy, V. 2004) Considering the terminology of value creation from a customer-centric perspective, the value is not created by the company. The organization is responsible for enabling, delivering, or facilitating the use of the service, and only through the usage can a customer create value. This notion determines that the firm and the customer are involved in different processes and using the value-in-use perspective implies that the company is engaged in the generation of potential value. In contrast, the customer is, alone, responsible for its usage and thus creating real value (Grönroos, 2011).

This interaction between the customer and organization should then influence a collaborative process of production (as co-producer, co-designer, and co-developer) and have a direct influence on the outcome of the service and value is co-created as depicted below:

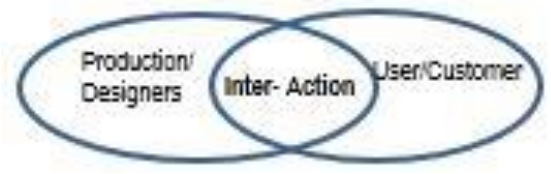

Figure1: Interaction between the customers and designers

\subsection{Theoretical Framework for Co-Creation in Interactive Product Development}

The active participation of customers/end users and designers/production is enabled through numerous interaction channels. Indeed, it is the advances of collaboration that have helped customers/end users to be much more active, knowledgeable, and globally aware of production environments to personalize and shape new products and services. The original product development moreover emerges using terminology that hesitates between two other values: user-driven and open collaboration. User-driven significantly distinguishes itself by promoting single participation, product-centric, and participatory approach to user involvement in the design of new products and services. However, it is just focusing on how customer participation. On the other hand, the open-innovation paradigm promotes a more generic and broader vision of the involvement landscape. It further articulates the critical mechanisms for inbound and outbound processes, intellectual property, participant knowledge, and resource flows used by firms to engage in a more proactive ecosystem.

Consequently, the participation of customers/end users and designers/production practices enables a broader and more systematic positioning of customers/end users across the entire product development lifecycle, leading to a significant enhancement of the userdriven potential. As a result, a collaboration between customers/end users and designers/production is increasingly recognized as a promising development strategy. The co-creation paradigm moreover positions the source of value within the co-creation experience, which is actualized through the company-customer interaction events. By co-creating with the network, the customer becomes an active stakeholder in defining both the interaction and the context of the event, including their specific personal meaning. The personal nature of the interactive experiences enables new dimensions of value which are based on the quality and the personal relevance of the interaction events, as well as on the opportunity for customers to co-create their unique end products, services, and experiences.

Figure II below illustrates how the roles of designers and customers may vary in many forms. Although this variedness was in the same domain, early engagement from the customer was notified. From inception, tools were provided by providers/ designers for a customer to engage with the co-creational design process. A total involvement from customers was acquainting from an early stage whereby customers themself are an early co-creator of products. This new theory diminished an old assumption used to places provider/ designers as an early provider of co-creational value. 


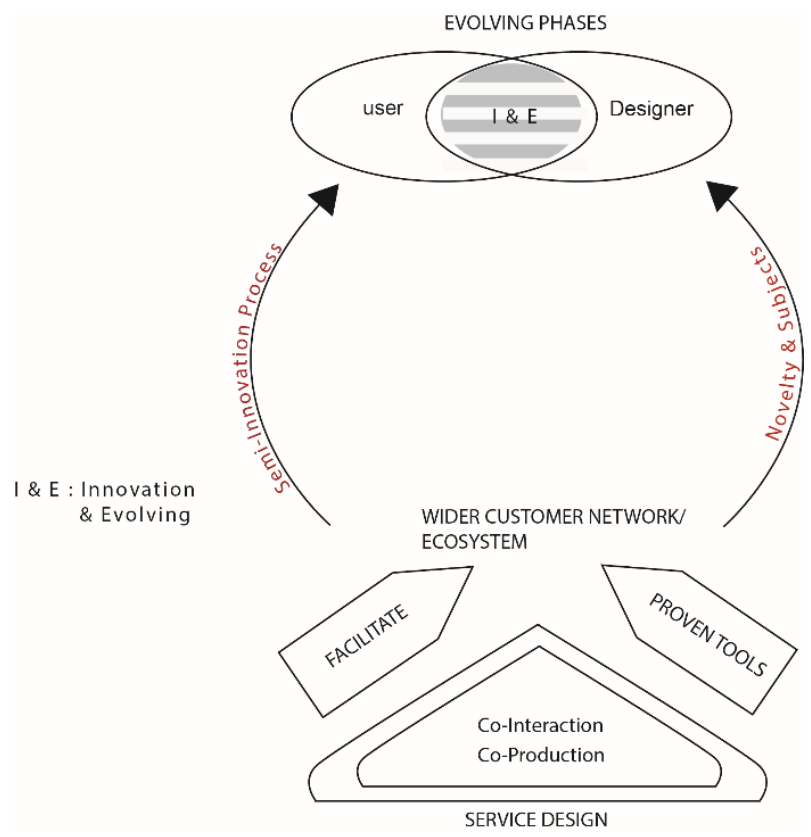

Figure 1: Theoretical Framework of Co-creation method for Interactive Product Development

\subsection{Conclusion}

This paper proposed a conceptual model of co-creation using the notion of digital eco-systems and assessed the impact of co-creation eco-systems on aspects of Malaysian interactive multimedia products. Hence, with a wider customer network system, the participation of customers to co-create with firms is high. The wider customer network is a result of advanced technology and the evolution of the internet and information technology. The emergence of this technology has benefited the interaction between customers and firms, whereby customers directly passed their thoughts and needs and get involved in the production process. Besides, the co-creation method has been adopted by firms slowly in the mission to create competitiveness and innovation for their products or services. Especially, if the vision of a company is to increase product value, the conventional value proposition design has to be re-analyze and the company or firm need to adapt the co-creation value method is advisable.

The notion of co-creation method as a multi-faceted is unique and brings values for holistic customer experience towards co-creation. Further, customer experience while engaging with a multi-faceted characteristic of co-creation is important to ensure future valuable values constantly created. Customer involvement is included multi-actors, whereby during production many actors other than customers are involving. Therefore, the actor has included firms employee upgraded to be a loyal business partner, while the internet and social media responsible for channel user or customers' thoughts and needs towards products or services. These were the multi-actors that engaging firms with multi-interactional values. Results, of $t$ this multi-interactional engagement with firms or firms representative, will create new future values for products and services

To summarize, the co-creation value method and it's a notion of customer holistic experience can be actualized in Malaysia, with Malaysia today is always keen to adapt to new concept and technology. Malaysia needs a new concept that can revoke a traditional system that has been practicing for the last 20 years after Malaysia celebrated its first multimedia corridor. The co-creation method and ultimate customer experiences of the core of value creation must be adapted in the interactive multimedia industry in Malaysia, to be competitive and innovative parallel with Malaysia's vision 2020.

\section{Acknowledgments}

The research presented in this paper has been supported by the Fundamental Research Grant (FRGS) Under the Ministry of Higher Education

\section{References}

Roser, T., Samson, A., Humphreys, P. and Cruz-Valdivieso, E., New pathways to value: co-creating products by collaborating with customers, LSE Enterprise, London, UK (2009) .

Ramaswamy, Venkat, and Francis Gouillart. Building the co-creative enterprise." Harvard Business Review 88.10 (2010): 100-109.

Venetis, K. and Ghauri, P. 'Service quality and customer retention', European Journal of Marketing, 2004, 38, 11/12, 1577-1598. 
Sørensen, E. \& J. Torfing, Enhancing collaborative innovation in the public sector, in: Administration \& Society, 2011, 43(8); 842-868.

A Wiewiora, R Keast \& K Brown (2015) Opportunities and Challenges in Engaging Citizens in the Co-Production of Infrastructure-Based Public Services in Australia in Public Management Review (published online: 10.1080/14719037.2014.999820).

Lusch, Robert F. and Nambisan, Satish. Service Innovation: A Service-Dominant Logic Perspective, MIS Quarterly, 2015, 39(1), 155-171.

Andreu, L.,Sanchez, I. and Mele, C. , Value co-creation among retailers and consumers: New insights into the furniture market, Journal of Retailing and Consumer Services, 2010, 17(4), 241-250.

Grönroos, C.Value co-creation in service logic: A critical analysis, Marketing Theory, 2011,11(3), 279-301.

Galvagno, M., et al. (2014). Theory of value co-creation: a systematic literature review. Managing Service Quality: An International Journal 24(6): 643-683. 